\title{
Understanding the determinants of users' continuance intention to buy low-cost airline flights online
}

\author{
Carlos Tam \\ Invited Assistant Professor \\ carlosvai@novaims.unl.pt \\ Phone: (+351) 213-828-610 \\ NOVA, Information Management School (NOVA IMS), Universidade NOVA de Lisboa, \\ Campus de Campolide, 1070-312 Lisboa, \\ Portugal \\ Maria Barroso \\ maria_sbarroso@live.com.pt \\ Phone: (+351) 213-828-610 \\ NOVA, Information Management School (NOVA IMS), Universidade NOVA de Lisboa, \\ Campus de Campolide, 1070-312 Lisboa, \\ Portugal \\ Frederico Cruz-Jesus \\ Assistant Professor \\ fjesus@novaims.unl.pt \\ Phone: (+351) 213-828-610 \\ NOVA, Information Management School (NOVA IMS), Universidade NOVA de Lisboa, \\ Campus de Campolide, 1070-312 Lisboa, \\ Portugal
}

This is the accepted author manuscript of the following article published by

EMERALD:

Tam, C., Barroso, M., \& Cruz-Jesus, F. (2022). Understanding the determinants of users' continuance intention to buy low-cost airline flights online. Journal of Hospitality and Tourism Technology, ahead-of-print(ahead-of-print). [Advanced online first on 10 February 2022].

https://doi.org/10.1108/JHTT-12-2020-0316

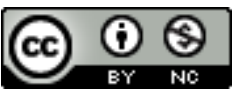

This work is licensed under a Creative Commons Attribution-NonCommercial 4.0 International License. 


\title{
Understanding the determinants of users' continuance intention to buy low-cost airline flights online
}

\begin{abstract}
Purpose - Low cost carriers' (LCC) worldwide market share is gaining momentum. This article proposes using the expectation confirmation model (ECM) combined with brand awareness and image, website quality, and visual appeal to evaluate the continuance use intention of low-cost airlines (LCA) websites.

Design/methodology/approach - The empirical approach was based on an online survey of 272 individuals collected in Portugal. The data were analyzed using structural equation modeling.

Findings - Brand awareness, brand image, and satisfaction are the variables that best explain continuance intention. The leftover constructs can empirically explain ECM.

Originality/value - This study seeks to understand the significance of brand awareness and image, website quality, and visual appeal in LCA websites' confirmation and continuance use intention. Understanding the influence on confirmation and long-term viability, strategies based on these conclusions are proposed for LCC companies to better promote consumers' continuance use intention.
\end{abstract}

Keywords: Continuance use intention; Expectation confirmation model (ECM); Low-cost carrier (LCC); Brand; Website

\section{Introduction}

The global low-cost carriers (LCC) market has grown at an impressive rate in the last decade. This growth is partially explained by the deregulation of aviation markets that opened several opportunities to greater competition (Graham, 2013) and the increased information available and willingness to travel. The emergence of this new sector led many airports to experience an impressive increase in passenger rates. Compared with the end of 2009, the LCC fleet doubled (CAPA, 2019). This naturally also affected the seating capacity of LCC, which has also doubled since 2009, amounting to 1.7 billion in 2018. Geographically, 35\% of the global LCC seats in 2018 pertain to the Asia Pacific, making this region the largest market in the world (CAPA, 2019).

Nevertheless, in Europe, LCC have the highest market share in the airline industry, perhaps because of the Schengen agreement. In 2009 the LCC penetration rate stood at $34 \%$, whereas in 2019 , it was $41 \%$. Seating capacity rose $78 \%$ in the last decade.

In the tourism literature, LCC have been gaining attention. Escobar-Rodríguez and Carvajal-Trujillo (2014), for example, studied the determinants of purchasing flights from LCC's website among Spanish consumers of LCC, concluding that online purchase intentions, habit, and ease of use were the most important variables. Chang and Hung (2013) assessed the drivers of LCC adoption and loyalty of passengers in Southeast Asia, finding that reduced tariffs and convenient booking channels can lower the length of time until adopting LCC and that airline image and safety consideration have the opposite effect. Topics such as adoption, loyalty, and satisfaction are often studied in the LCC context, leaving the continuance intention open to study. Based on that, and motivated by this research gap, we posit our research question $(R Q)$ : what are the drivers of continuance intention for LCA? 
In answering this $R Q$, we develop a research model based on the expectation-confirmation model (ECM), which is an empirically validated theoretical model by Bhattacherjee (2001), and four constructs from previous studies - brand awareness (Suki and Sasmita, 2015), brand image (Lien et al., 2015), website quality (O'Cass \& Carlson, 2012; Wells, Valacich, \& Hess, 2011), and visual appeal (Loureiro, 2014). By adding these four constructs to the ECM, which is the core theory related to satisfaction with continuance intention, we seek to explain the main drivers of LCC's continuance use intention. We expect this work to help researchers and practitioners understand the critical factors of the drivers to keep consumers booking LCC online. Thus, this work's contributions are twofold: first, by incorporating brand awareness and brand image to show how relevant it is to investigate the relationship with confirmation and continuance intention, this study helps us to understand the influence of the LCC brand on the confirmation and long-term viability; second, by combining website quality and visual appeal with the confirmation and continuance intention, we provide further insights on the drivers of effective use and continuance intention of LCC.

\section{Literature review and hypotheses}

\subsection{Low-cost airlines (LCA)}

Air transport markets' liberalization was the turning point, especially for LCC (Adler et al., 2014; Donzelli, 2010; Tsui, 2017). With globalization becoming a reality, deregulation and liberalization of air transportation were unavoidable for eradicating or relaxing some restrictions, including price, capacity, and entry. Several studies show that the spread of the airline industry and travel yield positive effects on countries' tourism and, as a result, their economies. In the Azores, for example, Vieira, Câmara, Silva, and Santos (2019) concluded that "tourism numbers increased sharply as more alternative choices emerged to visitors after the entrance of LCC due to airline liberalization". Donzelli (2010) studied the impact of LCC between 2000 and 2006 on the peripheral areas of Southern Italy, estimating an economic welfare growth of approximately $€ 14.6$ million per year, driven by low-cost routes, and additionally an increase in the international tourism and traffic deseasonality.

Identified and differentiated by operational characteristics and the service offered, the airline market is split into three business models - full-service airlines, LCC, and chartered flights (Lordan, 2014; Vieira et al., 2019). By cutting on service costs (e.g., complimentary meals), charging luggage fees, and using secondary airports, LCC can offer lower ticket prices (Chang and Hung, 2013). Some authors, such as Dobruszkes (2006), argue that "several airlines will probably disappear" since it is not a healthy market. In fact, in the last few years, some important LCC worldwide have ceased operations (e.g., Wow Air, Primera Air, or Air Berlin). On the other hand, the widespread use of selfservice applications by the consumer has allowed lower distribution costs by selling airline tickets directly to consumers through their websites (bypassing travel agents), point-to-point service (rather than hub-to-hub), and non-refundable tickets (Kim \& Lee, 2011). In the current study, we focus on continuance intention derived from LCC websites, applying the ECM model combined with brand awareness, brand image, website quality, and visual appeal to explain users' beliefs and behaviors to the continuance use.

\subsection{Expectation confirmation model (ECM) and hypotheses}

In recent years, employing adoption models to shed light on the determinants of consumers' LCC travel decisions has dominated LCC research. Most studies related to LCC have focused on adoption (Chang \& Hung, 2013; Escobar-Rodríguez \& Carvajal-Trujillo, 2014), stating that online purchase intention, habit, and ease of use are the most important determinants of LCC online 
purchasing. To the best of the authors' knowledge, no studies are focusing on the continuance intention of LCC travel. Seeking to fill this gap and expand the literature on this topic, we focus on actual continuance behavior rather than adoption intention, as there is evidence that the latter does not necessarily produce the first (Guinea and Markus, 2009).

Our proposed model is grounded on ECM, i.e., the relationship between confirmation, satisfaction, and continuance intention. To better understand it, we applied the ECM model, which theorizes information systems (IS) continuance, adapted from expectation confirmation theory (ECT), but which is focused on post-acceptance variables (Bhattacherjee, 2001). ECM states that "while postacceptance usefulness perception continues to influence users' continuance intention, user satisfaction with prior use has a relatively stronger effect on [IS continuance, and satisfaction] is determined primarily by users' confirmation of expectation from prior use and secondarily by perceived usefulness" (Bhattacherjee, 2001). The following list outlines the meaning of the ECM model dimensions:

- Perceived usefulness: is identified as a cognitive belief and broadly defined as a stage at which an individual considers that using a specific system or service will fulfill and reinforce his/her performance (Bhattacherjee, 2001). The perceived usefulness is based on the technology acceptance model (TAM) and is the strongest predictor of the usage continuance intention (Davis et al., 1989). In the IS literature, the positive relationship between perceived usefulness and satisfaction and continuance intention is well established.

- Confirmation: is determined by the extent to which an individual confirms or not his/her expectation. Having lower expectations linked with higher performance leads to greater confirmation (Bhattacherjee, 2001). Hence, greater confirmation relates lower expectations with higher perceived usefulness. Confirmation or disconfirmation can be related to satisfaction and dissatisfaction, respectively, in that lower expectations and higher perceived usefulness lead to a positive feeling of confirmation, which is the meaning of satisfaction.

- Satisfaction: is determined as an effect converted to a positive feeling (satisfaction), indifference, or a negative feeling (dissatisfaction). Satisfaction is positively related to repurchase intention (Bhattacherjee, 2001). Satisfaction is determined by users' expectations confirmation from previous experiences and perceived usefulness. It is considered a strong predictor to build and retain a loyal base of long-term consumers, reinforcing a user's intention to continue using the system (Nascimento et al., 2018).

- Continuance intention: is determined by consumers' satisfaction with previous use and is defined as an individual's intention to continually use or reuse a system (Bhattacherjee, 2001). Once an individual considers that using a determined system will achieve the expected outcome or performance, he/she will intend to use it repeatedly.

A broad spectrum of topics involving information systems can be investigated concerning ECM applications. These include matters such as continuance intention of video-on-demand services (Pereira and Tam, 2021) or e-health/m-health adoption and its improvements (Leung and Chen, 2019). Several investigations report consistent relationships of ECM with other models in different contexts, such as the UTAUT2 (Tam et al., 2020), theory of planned behavior (Kim, 2010), or innovation diffusion theory (Rahardja et al., 2019). Hence, we hypothesize:

\footnotetext{
H1: Confirmation has a positive impact on perceived usefulness.

H2: Perceived usefulness has a positive impact on continuance intention.

H3: Perceived usefulness has a positive impact on satisfaction.

H4: Confirmation has a positive impact on satisfaction.

H5: Satisfaction has a positive impact on continuance intention.
} 


\subsection{Brand awareness and brand image}

Our research model expands ECM by considering brand awareness and image, website quality, and visual appeal. Brand awareness refers to how consumers link the product to the brand and viceversa. When consumers want to purchase a product or service, and a brand name comes to their minds immediately, it means that the product or service has higher brand awareness (Suki and Sasmita, 2015). This, in turn, means that all of the marketing channels play an essential role by assuring the quality and credibility of the products/services. Brand awareness has a considerable impact on individuals' decision-making processes. According to Dabbous and Barakat (2020), brand awareness is a fundamental aspect that affects users' purchase intention. Bae et al. (2020) establish the relationship of brand awareness with brand association and brand loyalty, leading to customer satisfaction. The brand image also has an essential role in the consumer's decision about which brand to choose. It helps consumers discern a brand from others by identifying if his/her needs/wants are fulfilled by the brand (Anwar et al., 2011). Brand image is defined "as perceptions about a brand as reflected by the brand associations held in consumer memory" (Keller, 1993), meaning that the more positive the brand image is, the more willing the consumer is to use and continue to use the brand product/service and its attributes. As with brand awareness, brand image plays an essential role while the consumer makes her/his choice by associating his/her needs with a brand's purpose (Nam et al., 2011). Barreda et al. (2020) indicate that brand image in the social media context helps develop a favorable evaluation and generate a stronger emotional attachment with the brand. Prior studies have also shown that brand image predicts customer satisfaction and loyalty (Dam and Dam, 2021). Therefore, we posit:

H6a: Brand awareness has a positive impact on confirmation.

H6b: Brand awareness has a positive impact on continuance intention.

H7a: Brand image has a positive impact on confirmation.

H7b: Brand image has a positive impact on continuance intention.

\subsection{Website Quality}

According to some management information system researchers, there is no clear, uniform definition of website quality (Semerádová and Weinlich, 2020). This is so mainly because that definition can vary according to the perspective of a user or developer, for example. According to Rocha (2012), website quality can be considered in three domains: content, functionality, and technical aspects. Websites are a means of communication between the brands and the consumers whereby intrinsic and extrinsic product characteristics are exposed by pictures, virtual experiences, or even the price and website quality (Wells, Valacich, \& Hess, 2011). Everard and Galletta (2005) suggested that website quality impacts consumers' impressions about a brand and the product. Customers seek fast and precise information to decide quickly. Well organized information, icons, bullet points, and pictures are the easiest way to quickly understand if the product/service meets the user's needs or not. A website that allows the consumer to arrive at conclusions easily will encourage the consumer to search for more information and obtain more than what he/she was looking for at the outset. Website quality plays an essential role in attaining website effectiveness and customer loyalty (Candiwan and Wibisono, 2021). Customers are more likely to visit and purchase at websites that exhibit highly desirable qualities (Ali et al., 2021; Qalati et al., 2021). Thus, website quality may affect a user's usage and continuance intention. Therefore, we hypothesize:

H8a: Website quality has a positive impact on confirmation.

H8b: Website quality has a positive impact on continuance intention. 


\subsection{Visual Appeal}

"Eyes are the first to buy" is a simple expression that says a great deal about visual appeal. Bilro et al. (2018) identified visual appeal (website creativity, multimedia, color graphics, images, and animation) as one of the dimensions of website quality. Wells, Valacich, and Hess (2011) also found that visual appeal is the strongest determinant of website quality. The more the website or the information is well written and well organized, the more the consumers are willing to visit the website. As a dimension of website quality, visual appeal plays an essential role in a website's success by making the information enjoyable rather than presenting it as dull or unappealing (Guo et al., 2020). The journey through the website must be an experience that the consumers want to live again and again. Visual features are powerful in dictating consumer satisfaction and intent to purchase when they are elicited and experienced by the consumer (Jeon et al., 2021). Thus, the visual appeal may affect user continuance intention. For these reasons, we posit:

H9a: Visual Appeal has a positive impact on confirmation.

H9b: Visual Appeal has a positive impact on continuance intention.

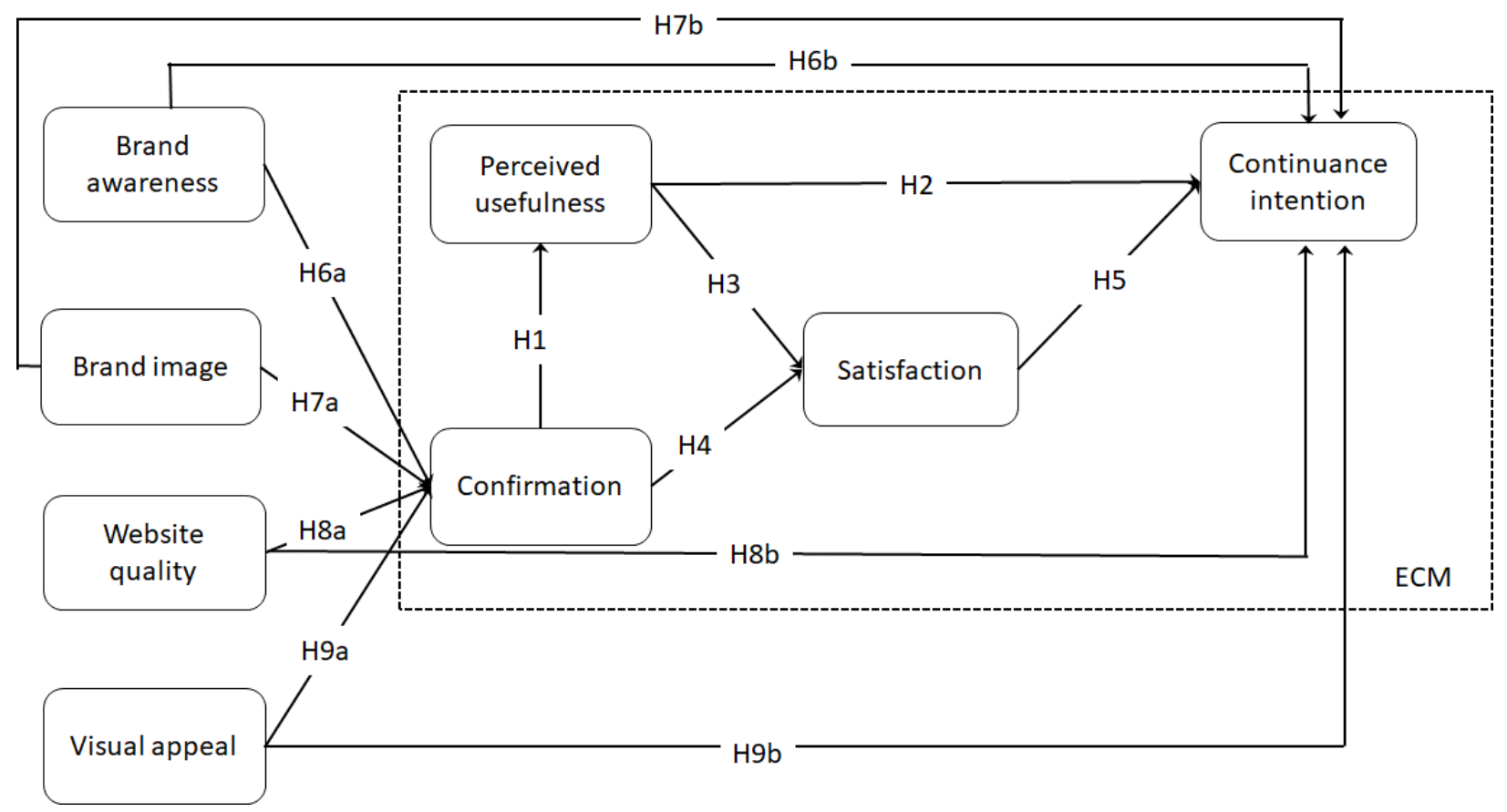

Figure 1 - Research Model

\section{Methodology}

The data were collected through a questionnaire on a well-known survey website between March and April of 2019. The questionnaire was first written in English and then translated to Portuguese, which was made available to respondents. The questionnaire was translated back to English to ensure translation consistency (Brislin, 1970). As shown in Appendix A, the items were adapted from the literature. The items were measured using a numerical scale ranging from strongly disagree (1) to strongly agree (7). Data collection occurred in two phases: in phase one, the questionnaire was applied to 30 persons (pilot) to test and analyze if the questionnaire had issues or problems. Based on the result of the pilot test, we concluded that the survey was valid, and we were able to move forward. Naturally, the pilot sample was not included in the final data. In phase two, we conducted the final survey. Due to the difficulty of fixing the sampling frame, there was no systematic sampling. 
The participants of this study are Portuguese persons who use Facebook. A total of 306 responses were collected, of which 272 were valid and considered for the analysis. To test for common method bias, Harman's one-factor test was applied (Podsakoff et al., 2003). The first factor only accounts for $41 \%$ of the variance, well below the threshold of $50 \%$. Hence, no significant common method bias was found. A marker variable technique was used in an additional test for common method bias (Lindell and Whitney, 2001; Malhotra et al., 2006). We added a theoretically irrelevant marker variable in the research model, obtaining $0.0241(2.41 \%)$ as the maximum shared variance with other variables; a value that can be considered as low (Johnson et al., 2011). No significant bias was found in the data set. Concerning the demographic indicators (see Table 1), 59\% of respondents are women, 55\% are between 18 and 29 years old, $83 \%$ are working professionals, and $73 \%$ had traveled with an airline company at least once. 
Table 1 - Descriptive statistics of respondents' characteristics

\begin{tabular}{|c|c|c|c|c|c|}
\hline \multicolumn{6}{|c|}{ Sociodemographic characteristics $(n=272)$} \\
\hline Age & & & Gender & & \\
\hline$<30$ & 150 & $55 \%$ & Male & 111 & $41 \%$ \\
\hline $30-40$ & 83 & $31 \%$ & Female & 161 & $59 \%$ \\
\hline$>40$ & 39 & $14 \%$ & & & \\
\hline Employment & & & Education & & \\
\hline Students & 33 & $12 \%$ & High school or below & 71 & $26 \%$ \\
\hline Working professionals & 225 & $83 \%$ & Bachelor's degree & 127 & $47 \%$ \\
\hline Unemployed & 10 & $4 \%$ & Master's degree or higher & 71 & $26 \%$ \\
\hline Retired & 1 & $0 \%$ & Other & 3 & $1 \%$ \\
\hline Student worker & 3 & $1 \%$ & & & \\
\hline
\end{tabular}

\section{Data analysis and results}

A partial least squares structural equation modeling (PLS-SEM) was performed supported on the software SmartPLS 3.2.7 (Ringle, C., Wende, S., and Becker, 2015). The analysis of the PLS-SEM was assessed in two parts: the measurement and structural models.

To assure the suitability of the measurement model, we assessed the construct reliability, indicator reliability, convergence validity, and discriminant validity, as suggested by Hair, Hult, Ringle, and Sarstedt (2016). The composite reliability (CR) and Cronbach's alpha (CA) values are greater than 0.7 , meaning that the model has a satisfactory internal consistency. To evaluate indicator reliability, loading should be above 0.7, and loading less than 0.4 should be excluded (Henseler et al., 2009). As all loadings are above 0.4 , no item had to be excluded. Since all items were higher than 0.7 , it suggests that the constructs are reliable (please see Appendix A). Table 2 shows a CR greater than 0.8 for all constructs, which is a suitable CR. The average variance extracted (AVE) was used to test convergent validity for each construct. While the AVE is greater than 0.5 , the latent variables explain more than half of the variance of their indicators (Hair et al., 2014; Henseler et al., 2009). Because the AVE is above 0.5 in our study, convergence is guaranteed. To ensure discriminant validity, the square root of AVE (diagonal values in bold) should be greater than the correlation between each pair of constructs (off-diagonal values) (Fornell and Larcker, 1981), which is reinforced if the loadings are greater than cross loadings (Chin, 1998; Hair et al., 2014). Thus, all eight of the constructs of our research model are statistically different and can be used to test the proposed model. Finally, the Heterotrait-Monotrait ratio (HTMT) criterion for discriminant validity assessment showed the presence of discriminant validity between the pair of constructs, as the HTMT ratios for each pair of constructs have a value lower than 0.9 and are significant, as shown in Table 3 (Henseler, Ringle, and Sarstedt, 2015).

Table 2 - AVE, standard deviations, correlations, and reliability and validity measures of latent variables

\begin{tabular}{|c|c|c|c|c|c|c|c|c|c|c|c|c|}
\hline Constructs & AVE & $\overline{S D}$ & $\mathrm{CR}$ & $\overline{\mathrm{CA}}$ & $\mathrm{BA}$ & $\overline{B l}$ & WQ & DVA & $\overline{P U}$ & $\mathrm{C}$ & $\bar{S}$ & $\mathrm{Cl}$ \\
\hline Brand awareness & 5.260 & 1.211 & .894 & .842 & .824 & & & & & & & \\
\hline Brand image & 4.742 & 1.114 & .849 & .762 & .276 & .765 & & & & & & \\
\hline Website quality & 4.619 & 1.139 & .906 & .863 & .376 & .555 & .842 & & & & & \\
\hline Visual appeal & 4.780 & 1.200 & .937 & .911 & .434 & .466 & .638 & .888 & & & & \\
\hline Perceived usefulness & 4.733 & 1.572 & .964 & .950 & .360 & .355 & .368 & .342 & .933 & & & \\
\hline Confirmation & 4.770 & 1.149 & .899 & .831 & .369 & .520 & .568 & .527 & .574 & .865 & & \\
\hline Satisfaction & 4.838 & 1.196 & .940 & .915 & .413 & .565 & 659 & .671 & .503 & .739 & .893 & \\
\hline Continuance intention & 5.317 & 1.221 & .909 & .867 & .486 & .565 & .559 & .508 & .428 & .568 & .636 & .845 \\
\hline
\end{tabular}

Note: Average variance extracted (AVE); standard deviations (SD); composite reliability (CR); Cronbach's alpha (CA) 
Table 3 - HTMT

\begin{tabular}{lllllllll}
\hline \multicolumn{1}{c}{ Constructs } & BA & BI & WQ & DVA & PU & C & S & Cl \\
\hline Brand awareness & & & & & & & & \\
Brand image & .341 & & & & & & & \\
Website quality & .432 & .682 & & & & & & \\
Visual appeal & .494 & .561 & .716 & & & & & \\
Perceived usefulness & .395 & .411 & .400 & .367 & & & & \\
Confirmation & .433 & .641 & .659 & .603 & .644 & & & \\
Satisfaction & .462 & .668 & .736 & .734 & .540 & .842 & & \\
Continuance intention & .557 & .673 & .622 & .557 & .466 & .650 & .692 & \\
\hline
\end{tabular}

Figure 2 presents the path coefficients of the proposed model resulting from the bootstrapping resampling method with 5,000 repetitions. The t values are computed to measure each indicator's weight's significance. The model explains $42.4 \%$ of the variation in confirmation. Brand awareness $(\widehat{\beta}=.118, p<.05)$, brand image $(\widehat{\beta}=.252, p<.01)$, website quality $(\widehat{\beta}=.262, p<.05)$, and visual appeal $(\widehat{\beta}=.191, p<.05)$ are statistically significant in explaining confirmation, concluding that $\mathrm{H} 6 \mathrm{a}, \mathrm{H} 7 \mathrm{a}$, $\mathrm{H} 8 \mathrm{a}$, and $\mathrm{H} 9 \mathrm{a}$ are supported. Our model can explain $32.9 \%$ of the variation in perceived usefulness. The confirmation $(\hat{\beta}=.574, p<.01)$ is statistically significant in explaining perceived usefulness, supporting $\mathrm{H} 1$. The model explains $55.6 \%$ of the variation in satisfaction. The confirmation $(\widehat{\beta}=.671$, $p<.01)$ and perceived usefulness $(\hat{\beta}=.118, p<.10)$ are statistically significant in explaining satisfaction, supporting hypotheses $\mathrm{H} 3$ and $\mathrm{H} 4$. As for continuance intention, our model can explain $53 \%$ of its variation. The satisfaction $(\widehat{\beta}=.287, p<.01)$, brand awareness $(\widehat{\beta}=.229, p<.01)$, and brand image $(\hat{\beta}=.248, p<.01)$, are statistically significant in explaining continuance intention, supporting hypotheses $\mathrm{H} 5, \mathrm{H} 6 \mathrm{~b}$, and $\mathrm{H} 7 \mathrm{~b}$. The perceived usefulness, website quality, and visual appeal are statistically insignificant to explain continuance intention, thus meaning that $\mathrm{H} 2, \mathrm{H} 8 \mathrm{~b}$, and $\mathrm{H} 9 \mathrm{~b}$ are not supported.

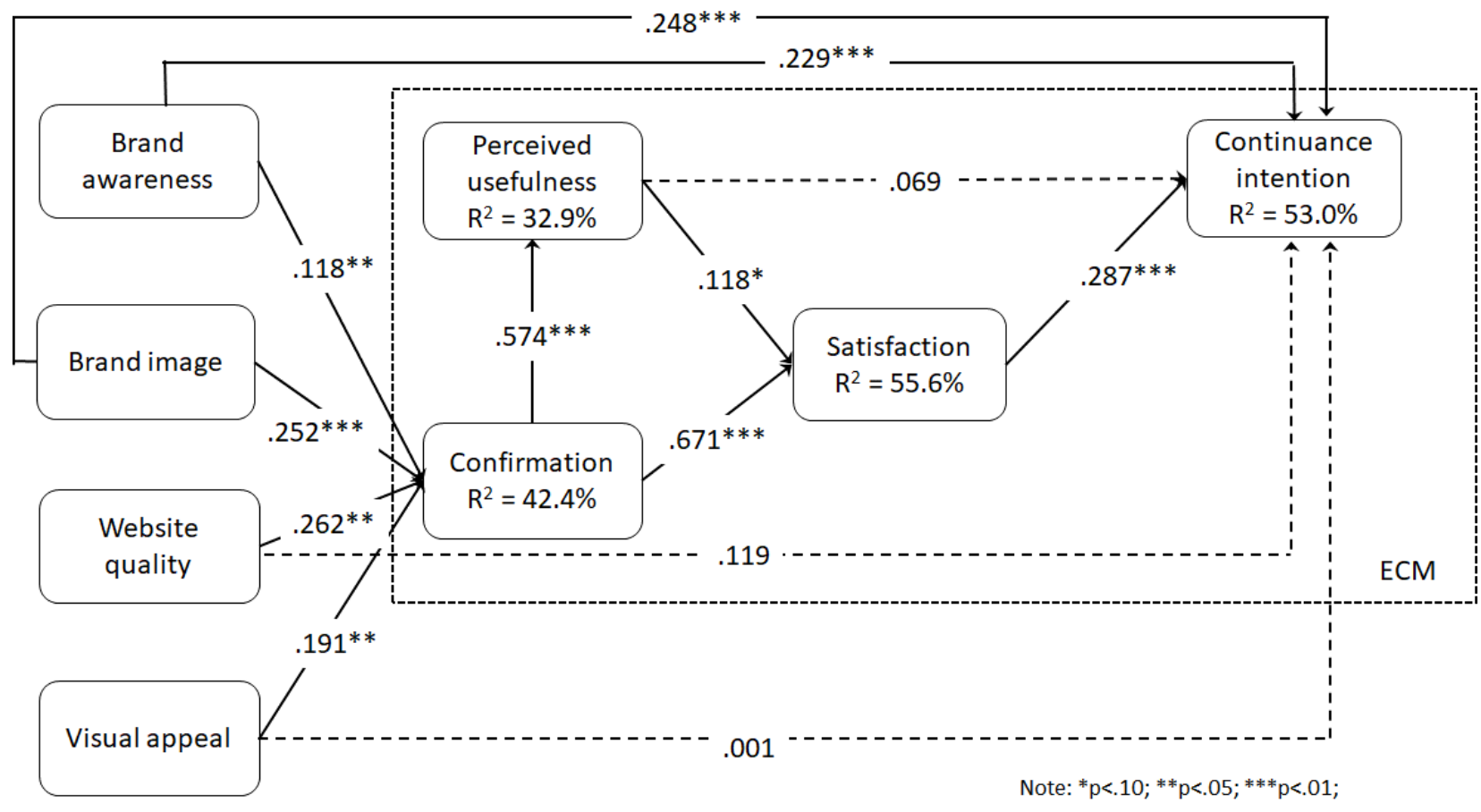

Figure 2 - Structural model results 


\section{Discussions and conclusions}

\subsection{Conclusion}

We sought to explain the main determinants of LCC use and continuance intention websites to purchase flights. To this end, we considered four determinants in our research model - brand awareness, brand image, website quality, and visual appeal. As far as we can ascertain, this is the first study investigating ECM considering these four dimensions' effect on the continuance intention. Ten of the 13 hypotheses were confirmed, demonstrating our model's theoretical suitability and consistency.

As shown by the analysis of Figure 2, our research model accounts for $42.4 \%$ of the variation in confirmation, supporting hypotheses $\mathrm{H} 6 \mathrm{a}, \mathrm{H} 7 \mathrm{a}, \mathrm{H} 8 \mathrm{a}$, and $\mathrm{H} 9 \mathrm{a}$. These results show that all four independent dimensions are significantly and positively associated with confirmation. The model also explains $32.9 \%$ of the variation in perceived usefulness, thus supporting $\mathrm{H} 1$. We were also able to explain $55.6 \%$ of the variation in satisfaction. Perceived usefulness and confirmation were significantly and positively associated with satisfaction, thus supporting $\mathrm{H} 3$ and $\mathrm{H} 4$. Finally, the research model explains $53 \%$ of the variation in continuance intention, supporting $\mathrm{H} 5, \mathrm{H} 6 \mathrm{~b}$, and $\mathrm{H} 7 \mathrm{~b}$. Hence, hypotheses $\mathrm{H} 2, \mathrm{H} 8 \mathrm{~b}$, and $\mathrm{H} 9 \mathrm{~b}$ are not supported by our model. If we compare the results of our research model to those of ECM alone (see Figure 3), we see that our model clearly outperforms the former, as the explained variation in continuance intention - the primary dependent variable increases by nine percentage points(p.p.). According to Hair, Hult, Ringle, and Sarstedt (2016), a value of R-squared at .75, .50, or .25 are considered as substantial, moderate, or weak, respectively. As shown in Figure 2, the R-squared values for the satisfaction (55.6\%) and continuance intention $(53 \%)$ are considered moderate. Perceived usefulness $(32.9 \%)$ and confirmation $(42.4 \%)$ are considered weak.

\subsection{Theoretical implications}

The theoretical implications of this research can be summarized in four main points. First, the theoretical contribution of this study is the combination of ECM with the four independent variables - brand awareness, brand image, website quality, and visual appeal - which we found and empirically demonstrated to be critical drivers of LCC. The inclusion of these four constructs is demonstrated to outperform ECM alone, which is the basis of our research model. Our research model increased by nine p.p. the variation explained in continuance intention - the primary (dependent) variable of interest. This fact highlights the importance of researchers combining different theories to develop tailor-made models for the technology under study, thereby improving their findings. Perhaps a paradigmatic example of the importance of this approach is the study conducted by (Liang and Shiau, 2018), who have also grounded on the ECM to explore the drivers of online repurchase intention in the context of airline tickets. However, in their study, the authors found perceived usefulness to be a significant driver of repurchase intention, whereas we did not. We believe that this difference has precisely to do with the fact that we have included other determinants that these authors did not, thus highlighting the importance of developing comprehensive models in the context of consumer behavior.

Second, our research model was applied in the context of LCC websites, assessing the consumers' continuance intention, a far more important feature than the intention to adopt, in the author's opinion. Besides continuance intention, confirmation, perceived usefulness, and satisfaction were also considered. Although a few studies have approached this concept, our research can be adapted to different types of online purchases, such as fashion, technology, or food. 
Third, with the association of the four constructs with the ECM, this study shows that there are other important constructs to pay attention to beyond satisfaction and perceived usefulness in explaining continuance intention, specifically brand awareness and image, that play a significant role in the decision context on confirmation and continuance intention. Some studies have examined the role of brand awareness over purchase intention (e.g., Dabbous and Barakat, 2020), and brand image over customer loyalty (Dam and Dam, 2021). This study explores the impact of brand awareness and brand image on the confirmation and continuance intention, demonstrating to future researchers how important it is to explore short and long-term viability. In this context, it is interesting that our study adds some novelty in respect to other studies conducted recently in LCC. Bigne et al. (2018), for example, studied the impact that external influences (i.e., media and experts' opinions about brands) have on LCC online repurchase intention. These authors conclude that these influences are not associated with repurchase intention, where we find evidence at least partially that they do (H6b and $\mathrm{H} 7 \mathrm{~b}$ ). We believe that this apparent, at least, at first sight, contradiction may be related to the fact that these authors only focused on travelers who had at least one active account in a social media networking travel site. It seems reasonable to assume that these individuals may have been more overexposed to external influences, or at least more than a typical (offline) consumer is. Therefore, in an environment full of external influence, it is only natural that these lose some strength gradually.

Fourth, the findings show that website quality and visual appeal tend to engage the initial expectations of the LCC users to interact with the website. Overall, website quality significantly impacts foreigners' decisions to visit a country, making the website an essential vehicle for tourism attraction (Alderighi and Gaggero, 2019). Although our results show that website quality and visual appeal play no role in continuance intention, they reveal that these features influence the usage decision. Although in the long-term perspective (continuance intention), these two constructs have no significance, when looking for the short-term perspective (adoption or intention), several studies identify website quality as an influencing factor on intention (Ali, 2016). A website's quality and appeal keep the consumers on the website and induce interest in the information or communication. After that, if the consumer is satisfied, the website no longer plays a decisive role. After that, brand awareness and brand image come into play to keep (or not) the consumer and let him/her continue with the brand, product, or service. This term-perspective difference plays an important role when determining a company's strategy depending on whether the target is short-term or long-term, adoption or continuance. Our results reveal that perceived usefulness shows no statistical significance in explaining continuance intention, which contradicts the literature (e.g., Foroughi et al., 2019; Nascimento et al., 2018). To the best of our knowledge, the present work is the first to test the impact of brand awareness, brand image, website quality, and visual appeal on confirmation and continuance intention.

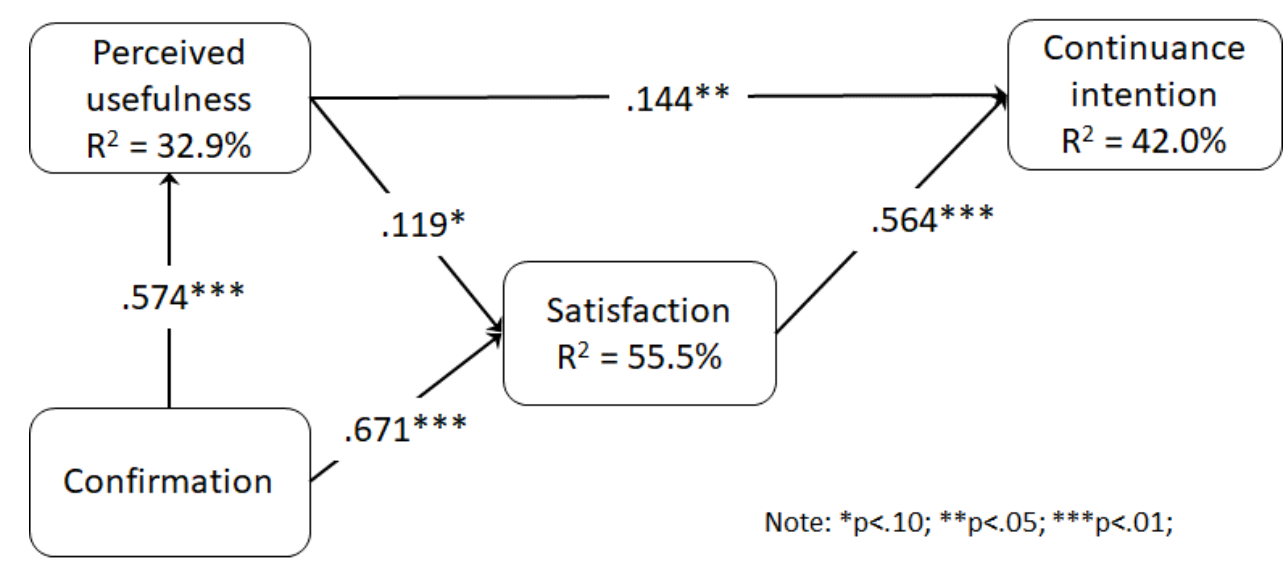


Figure 3 - Results obtained by original ECM

\subsection{Practical implications}

The results of this work bring new insights about individuals' continuance intention to buy LCC tickets online. First, we demonstrate that every ECM construct except perceived usefulness, brand awareness, and image are essential in explaining continuance intention. This fact offers some insights to LCC managers to promote users' online purchase continuance intention. For example, given the significance of brand awareness and brand image, companies should develop and boost all the perspectives around the brand to effectively communicate and spread brand recognition. According to Branding (2019), the brand positioning strategy is essential to create a positive bond to the product or service. Brands become embedded in the consumer's mind and help them make sense of and apply positioning to various products and services.

Second, visual appeal and website quality are not significant in explaining continuance intention must also be considered. LCC may gain popularity and competitive advantage by continuously improving the overall quality of their websites (Foroudi et al., 2019). The website communicates with the customers and lets them know brands' values and missions, which will come to the customers' minds when facing a brand stimulus. Some of the most important LCC worldwide have recently increased their marketing and communication budget (see, e.g., EasyJet, 2019; Qantas, 2019). It reveals that companies are aware that it is essential to develop all the perspectives around a brand, such as awareness and image, which is one of the demonstrations of the present research.

Third, companies should also be watchful about satisfaction, as it significantly affects continuance intention by developing customers' positive feelings (satisfaction) toward contacting the brand and the service/product.

Finally, the present study presents empirical evidence of the contribution of brand awareness, brand image, website quality, and visual appeal in confirmation of expectation. Therefore, focusing on these dimensions will result in a higher confirmation level. For instance, according to the Joy Ness Marketing portal (Joy Ness, 2021), focusing on the brand may help increase the value of products and services by differentiating them from the competition, creating positive mental associations, and forming relationships with customers. On the other hand, the website's quality can help foster a climate of consumers' trust, leading to the use of a website. The visual appeal of a website is the strongest determinant of website quality (Wells et al., 2011).

\subsection{Limitations and future research}

Our research has some limitations that need to be acknowledged. One is the use of only four independent variables adapted from other studies. In this sense, it is possible that our research model might not fully cover some important drivers behind LCC online purchase continuance and, therefore, should be included in future studies (e.g., incentives from frequent flyer programs or customer support). Including other variables related to well-being would be interesting in future studies and could offer more insights on LCC companies and their customers. Another limitation is the use of data from respondents of only one country. We suggest applying the same study or similar studies to different countries to investigate if the conclusions differ. Also, including some cultural variables would be interesting to understand if there are changes in the continuance intention. 


\section{References}

Adler, N., Fu, X., Oum, T.H. and Yu, C. (2014), "Air transport liberalization and airport slot allocation: The case of the Northeast Asian transport market", Transportation Research Part A: Policy and Practice, Vol. 62, pp. 3-19.

Alderighi, M. and Gaggero, A.A. (2019), "Flight availability and international tourism flows", Annals of Tourism Research, Vol. 79, p. 102642.

Ali, F. (2016), "Hotel website quality, perceived flow, customer satisfaction and purchase intention", Journal of Hospitality and Tourism Technology, Vol. 7 No. 2, pp. 213-228.

Ali, F., Terrah, A., Wu, C., Ali, L. and Wu, H. (2021), "Antecedents and consequences of user engagement in smartphone travel apps", Journal of Hospitality and Tourism Technology, Vol. 12 No. 2, pp. 355-371.

Anwar, A., Gulzar, A., Sohail, F. Bin and Akram, S.N. (2011), "Impact of brand image, trust and affect on consumer brand extension attitude: The mediating role of brand loyalty", International Journal of Economics and Management Sciences, Vol. 1 No. 5, pp. 73-79.

Bae, S., Jung, T.H., Moorhouse, N., Suh, M. and Kwon, O. (2020), "The influence of mixed reality on satisfaction and brand loyalty in cultural heritage attractions: A brand equity perspective", Sustainability, Vol. 12 No. 7, p. 2956.

Barreda, A.A., Nusair, K., Wang, Y., Okumus, F. and Bilgihan, A. (2020), "The impact of social media activities on brand image and emotional attachment", Journal of Hospitality and Tourism Technology, Vol. 11 No. 1, pp. 109-135.

Bhattacherjee. (2001), "Understanding information systems continuance: an expectationconfirmation model", MIS Quarterly, Vol. 25 No. 3, pp. 351-370.

Bigne, E., Andreu, L., Hernandez, B. and Ruiz, C. (2018), "The impact of social media and offline influences on consumer behaviour. An analysis of the low-cost airline industry", Current Issues in Tourism, Vol. 21 No. 9, pp. 1014-1032.

Bilro, R.G., Loureiro, S.M.C. and Ali, F. (2018), "The role of website stimuli of experience on engagement and brand advocacy", Journal of Hospitality and Tourism Technology, Vol. 9 No. 2, pp. 204-222.

Branding News (2019), "Brand positioning in the consumer's mind", available at: https://www.smart-marketingnews.com/branding/brand-positioning-in-the-consumers-mind (accessed 28 January 2020).

Brislin, R.W. (1970), "Back-translation for cross-cultural research", Journal of Cross-Cultural Psychology, Vol. 1, pp. 185-216.

Candiwan, C. and Wibisono, C. (2021), "Analysis of the Influence of Website Quality to Customer's Loyalty on E-Commerce", International Journal of Electronic Commerce Studies, Vol. 12 No. 1, pp. 83-102.

CAPA. (2019), "LCCs: global market share gains led by emerging markets".

Chang, L.Y. and Hung, S.C. (2013), "Adoption and loyalty toward low cost carriers: The case of Taipei-Singapore passengers", Transportation Research Part E: Logistics and Transportation Review, Vol. 50, pp. 29-36.

Chin, W.W. (1998), "Issues and opinion on structural equation modeling", MIS Quarterly, Vol. 22 No. 1, pp. 7-16.

Dabbous, A. and Barakat, K.A. (2020), "Bridging the online offline gap: Assessing the impact of brands' social network content quality on brand awareness and purchase intention", Journal of Retailing and Consumer Services, Vol. 53, p. 101966.

Dam, S.M. and Dam, T.C. (2021), "Relationships between service quality, brand image, customer satisfaction, and customer loyalty", The Journal of Asian Finance, Economics and Business, 
Vol. 8 No. 3, pp. 585-593.

Davis, F.D., Bagozzi, R.P. and Warshaw, P.R. (1989), “User acceptance of computer technology: a comparison of two theoretical models", Management Science, Vol. 35, pp. 982-1003.

Dobruszkes, F. (2006), "An analysis of European low-cost airlines and their networks", Journal of Transport Geography, Vol. 14 No. 4, pp. 249-264.

Donzelli, M. (2010), "The effect of low-cost air transportation on the local economy evidence from Southern Italy", Journal of Air Transport Management, Vol. 16 No. 3, pp. 121-126.

EasyJet. (2019), “2019 Annual report and accounts”.

Escobar-Rodríguez, T. , Carvajal-Trujillo, E. (2014), "Online purchasing tickets for low cost carriers: An application of the unified theory of acceptance and use of technology (UTAUT) model", Tourism Management, Vol. 43, pp. 70-88.

Everard, A. and Galletta, D.F. (2005), "How presentation flaws affect perceived site quality, trust, and intention to purchase from an online store", Journal of Management Information Systems, Vol. 22 No. 3, pp. 55-95.

Fornell, C. and Larcker, D.F. (1981), "Evaluating Structural Equation Models with Unobservable Variables and Measurement Error", Journal of Marketing Research, Vol. 18 No. 1, pp. 39-50.

Foroudi, P., Yu, Q., Gupta, S. and Foroudi, M.M. (2019), "Enhancing university brand image and reputation through customer value co-creation behaviour", Technological Forecasting and Social Change, Vol. 138, pp. 218-227.

Foroughi, B., Iranmanesh, M. and Hyun, S.S. (2019), "Understanding the determinants of mobile banking continuance usage intention", Journal of Enterprise Information Management, Vol. 32 No. 6, pp. 1015-1033.

Graham, A. (2013), "Understanding the low cost carrier and airport relationship: A critical analysis of the salient issues", Tourism Management, Vol. 36, pp. 66-76.

Guinea, A.O. and Markus, M.L. (2009), "Why break the habit of a lifetime? Rethinking the roles of intention, habit, and emotion in continuing information technology use", MIS Quarterly, Vol. 33, pp. 433-444.

Guo, L., Hu, X., Wei, X. and Cai, X. (2020), "The influence of personal motivation and environmental stimuli on customer participation and engagement behavior: the mediating role of experience evaluation", Journal of Hospitality and Tourism Technology, Vol. 11 No. 4, pp. 643-666.

Hair, J.F., Sarstedt, M., Hopkins, L. and Kuppelwieser, V.G. (2014), "Partial least squares structural equation modeling (PLS-SEM): An emerging tool in business research", European Business Review, Vol. 26 No. 2, pp. 106-121.

Hair Jr, J.F., Hult, G.T.M., Ringle, C. and Sarstedt, M. (2016), A Primer on Partial Least Squares Structural Equation Modeling (PLS-SEM), Sage Publications.

Henseler, J., Ringle, C.M. and Sarstedt, M. (2014), "A new criterion for assessing discriminant validity in variance-based structural equation modeling", Journal of the Academy of Marketing Science, Vol. 43 No. 1, pp. 115-135.

Henseler, J., Ringle, C.M. and Sinkovics, R.R. (2009), "The use of partial least squares path modeling in international marketing", New Challenges to International Marketing, Vol. 20, pp. 277-319.

Jeon, M.M., Jeong, M. and Lee, S.A. (2021), "The role of customers' motivations in the relationships between e-stimuli and behavioral intention on a bed and breakfast website", Journal of Hospitality and Tourism Technology, Vol. 12 No. 1, pp. 124-140.

Johnson, R.E., Rosen, C.C. and Djurdjevic, E. (2011), "Assessing the impact of common method variance on higher order multidimensional constructs.", Journal of Applied Psychology, Vol. 96 No. 4, pp. 744-761. 
Keller, K.L. (1993), "Conceptualization, measuring and managing consumer based brand equity", Journal of Marketing, Vol. 57 No. 1, pp. 1-22.

Kim, B. (2010), "An empirical investigation of mobile data service continuance: Incorporating the theory of planned behavior into the expectation-confirmation model", Expert Systems with Applications, Vol. 37 No. 10, pp. 7033-7039.

Kim, Y.K. and Lee, H.R. (2011), "Customer satisfaction using low cost carriers", Tourism Management, Vol. 32 No. 2, pp. 235-243.

Leung, L. and Chen, C. (2019), "E-health/m-health adoption and lifestyle improvements: Exploring the roles of technology readiness, the expectation-confirmation model, and health-related information activities", Telecommunications Policy, Vol. 43 No. 6, pp. 563-575.

Liang, C.-C. and Shiau, W.-L. (2018), "Moderating effect of privacy concerns and subjective norms between satisfaction and repurchase of airline e-ticket through airline-ticket vendors", Asia Pacific Journal of Tourism Research, Vol. 23 No. 12, pp. 1142-1159.

Lien, C.H., Wen, M.J., Huang, L.C. and Wu, K.L. (2015), "Online hotel booking: The effects of brand image, price, trust and value on purchase intentions", Asia Pacific Management Review, Vol. 20 No. 4, pp. 210-218.

Lindell, M.K. and Whitney, D.J. (2001), "Accounting for common method variance in crosssectional research designs", Journal of Applied Psychology, Vol. 86 No. 1, pp. 114-121.

Lordan, O. (2014), "Study of the full-service and low-cost carriers network configuration", Journal of Industrial Engineering and Management, Vol. 7 No. 5, pp. 1112-1123.

Loureiro, S.M.C. (2014), "The Formation of the Tourist' s Loyalty How Does It Affect Price Discounts?", International Journal of Tourism Research, Vol. 9, pp. 453-464.

Malhotra, N.K., Kim, S.S. and Patil, A. (2006), "Common method variance in IS research: A comparison of alternative approaches and a reanalysis of past research", Management Science, Vol. 52, pp. 1865-1883.

Joy Ness Marketing (2021), "The Importance of Brand Strategy", available at: https://joynessmarketing.biz/the-importance-of-brand-strategy/ (accessed 11 June 2021).

Nam, J., Ekinci, Y. and Whyatt, G. (2011), "Brand equity, brand loyalty and consumer satisfaction", Annals of Tourism Research, Vol. 38 No. 3, pp. 1009-1030.

Nascimento, B., Oliveira, T. and Tam, C. (2018), "Wearable technology: What explains continuance intention in smartwatches?", Journal of Retailing and Consumer Services, Vol. 43, pp. 157-169.

O'Cass, A. and Carlson, J. (2012), "An e-retailing assessment of perceived website-service innovativeness: Implications for website quality evaluations, trust, loyalty and word of mouth", Australasian Marketing Journal (AMJ), Vol. 20 No. 1, pp. 28-36.

Pereira, R. and Tam, C. (2021), "Impact of enjoyment on the usage continuance intention of videoon-demand services", Information \& Management, Vol. 58 No. 7, p. 103501.

Podsakoff, P.M., MacKenzie, S.B., Lee, J.-Y. and Podsakoff, N.P. (2003), "Common method biases in behavioral research: a critical review of the literature and recommended remedies.", Journal of Applied Psychology, Vol. 88 No. 5, pp. 879-903.

Qalati, S.A., Vela, E.G., Li, W., Dakhan, S.A., Hong Thuy, T.T. and Merani, S.H. (2021), "Effects of perceived service quality, website quality, and reputation on purchase intention: The mediating and moderating roles of trust and perceived risk in online shopping", Cogent Business \& Management, Vol. 8 No. 1, p. 1869363.

Qantas. (2019), “Qantas Annual Report 2019”.

Rahardja, U., Hariguna, T. and Aini, Q. (2019), “Understanding the Impact of Determinants in Game Learning Acceptance: An Empirical Study.", International Journal of Education and Practice, Vol. 7 No. 3, pp. 136-145. 
Ringle, C., Wende, S., \& Becker, J. (2015), "SmartPLS 3", available at: http://www.smartpls.com.

Rocha, Á. (2012), "Framework for a global quality evaluation of a website", Online Information Review, Vol. 36 No. 3, pp. 374-382.

Semerádová, T. and Weinlich, P. (2020), "Looking for the Definition of Website Quality BT Website Quality and Shopping Behavior: Quantitative and Qualitative Evidence", in Semerádová, T. and Weinlich, P. (Eds.), , Cham, pp. 5-27.

Suki, J.S.N.M. and Sasmita, J. (2015), "Young consumers' insights on brand equity: Effects of brand association, brand loyalty, brand awareness, and brand image", International Journal of Retail \& Distribution Management, Vol. 43 No. 3, pp. 276-292.

Tam, C., Santos, D. and Oliveira, T. (2020), "Exploring the influential factors of continuance intention to use mobile Apps: Extending the expectation confirmation model", Information Systems Frontiers, Vol. 2, pp. 243-257.

Tsui, K.W.H. (2017), "Does a low-cost carrier lead the domestic tourism demand and growth of New Zealand?", Tourism Management, Vol. 60, pp. 390-403.

Vieira, J., Câmara, G., Silva, F. and Santos, C. (2019), "Airline choice and tourism growth in the Azores", Journal of Air Transport Management, Vol. 77, pp. 1-6.

Wells, J.D., Valacich, J.S. and Hess, T.J. (2011), "What signal are you sending? How website quality influences perceptions of product quality and purchase intentions", MIS Quarterly, Vol. 35 No. 2, pp. 373-396.

Wells Valacich, J. S., \& Hess, T. J., J.D. (2011), "What signal are you sending? How website quality influences perceptions of product quality and purchase intentions", MIS Quarterly, Vol. 35 No. 2, pp. 373-396. 
Appendix A - Variables and indicators statistics

\begin{tabular}{|c|c|c|c|}
\hline Constructs & Items & Loadings & Adapted from \\
\hline $\begin{array}{l}\text { Brand } \\
\text { awareness }\end{array}$ & $\begin{array}{l}\text { BA1 - I am aware of this particular product/brand that appeared in the social media } \\
\text { BA2 - I can recognize this particular product/brand in comparison with the other } \\
\text { competing product/ brand that appeared in the social media } \\
\text { BA3 - I know what this particular product/brand looks like } \\
\text { BA4 - I can quickly recall symbol or logo of the particular product/brand that } \\
\text { appeared in the social media }\end{array}$ & $\begin{array}{l}.826 \\
.880 \\
.808 \\
.780\end{array}$ & $\begin{array}{l}\text { (Suki and Sasmita, } \\
\text { 2015) }\end{array}$ \\
\hline Brand image & $\begin{array}{l}\text { BI1 - The LCA brand is reliable } \\
\text { BI2 - The LCA brand is attractive } \\
\text { BI3 - The LCA brand is pleasing } \\
\text { BI4 - The LCA brand has a good reputation }\end{array}$ & $\begin{array}{l}.831 \\
.689 \\
.773 \\
.759\end{array}$ & (Lien et al., 2015) \\
\hline $\begin{array}{l}\text { Website } \\
\text { quality }\end{array}$ & $\begin{array}{l}\text { WQ1 - The quality of the LCA website is excellent } \\
\text { WQ2 - The quality of the LCA website is valuable } \\
\text { WQ3 - The quality of the LCA website is high standard } \\
\text { WQ4 - How would you rate the quality of LCA websites }\end{array}$ & $\begin{array}{l}.853 \\
.797 \\
.836 \\
.878\end{array}$ & $\begin{array}{l}\text { (O'Cass and Carlson, } \\
2012 \text { ) \& } \\
\text { (Wells Valacich, J. S. } \\
\text { \& Hess, T. J., 2011) }\end{array}$ \\
\hline $\begin{array}{l}\text { Visual } \\
\text { appeal }\end{array}$ & $\begin{array}{l}\text { DVA1 - Website looks attractive } \\
\text { DVA2 - Website looks organized } \\
\text { DVA3 - Website uses multimedia features properly } \\
\text { DVA4 - The website is visually appealing }\end{array}$ & $\begin{array}{l}.874 \\
.877 \\
.896 \\
.905\end{array}$ & (Loureiro, 2014) \\
\hline $\begin{array}{l}\text { Perceived } \\
\text { usefulness }\end{array}$ & $\begin{array}{l}\text { PU1 - Using LCA websites improves my performance in managing personal } \\
\text { finances } \\
\text { PU2 - Using LCA websites increases my productivity in managing personal } \\
\text { finances } \\
\text { PU3 - Using LCA websites enhances my effectiveness in managing personal } \\
\text { finances } \\
\text { PU4 - Overall, LCA websites are useful in managing personal finances }\end{array}$ & $\begin{array}{l}.919 \\
.944 \\
.945 \\
.923\end{array}$ & (Bhattacherjee, 2001) \\
\hline Confirmation & $\begin{array}{l}\text { C1 - My experience with using LCA websites was better than what I expected } \\
\text { C2 - The service level provided by LCA websites was better than what I expected } \\
\text { C3 - Overall, most of my expectations from using LCA websites were confirmed }\end{array}$ & $\begin{array}{l}.861 \\
.878 \\
.855\end{array}$ & (Bhattacherjee, 2001) \\
\hline Satisfaction & $\begin{array}{l}\text { S1 - How do you feel about your overall experience of LCA websites } \\
\text { Use: Very dissatisfied/Very satisfied } \\
\text { S2 - How do you feel about your overall experience of LCA websites } \\
\text { Use: Very displeased/Very pleased } \\
\text { S3 - How do you feel about your overall experience of LCA websites } \\
\text { Use: Very frustrated/Very contented } \\
\text { S4 - How do you feel about your overall experience of LCA websites } \\
\text { Use: Absolutely terrible/Absolutely delighted }\end{array}$ & $\begin{array}{l}.898 \\
.916 \\
.905 \\
.851\end{array}$ & (Bhattacherjee, 2001) \\
\hline $\begin{array}{l}\text { Continuance } \\
\text { intention }\end{array}$ & $\begin{array}{l}\text { Cl1 - After reviewing the LCA website, the likelihood of booking this airline is high } \\
\text { Cl2 - If I am going to book the LCA, I would consider booking this airline at the } \\
\text { price shown } \\
\text { Cl3 - The probability that I would consider booking these airlines is high } \\
\text { Cl4 - My willingness to book these airlines is high }\end{array}$ & $\begin{array}{l}.835 \\
.765 \\
.901 \\
.874\end{array}$ & (Lien et al., 2015) \\
\hline
\end{tabular}

${ }^{\mathrm{i}}$ Corresponding author 